\title{
Lactococcus lactis as a live delivery vector
}

\author{
Azizpour $\mathbf{M}^{1}$, Hosseini SD $^{2^{*}}$, Jafari $\mathbf{P}^{3}$, Akbary $\mathbf{N}^{3}$ \\ ${ }^{1}$ Young Researchers and Elite Club, Arak Branch, Islamic Azad University, Arak, Iran. \\ ${ }^{2}$ Razi Vaccine and Serum Research Institute, Agricultural Research, Education and Extension Organization (AREEO), Arak, \\ Iran. \\ ${ }^{3}$ Department of Microbiology, Islamic Azad University, Arak Branch, Arak, Iran.
}

\begin{abstract}
Mucosal surfaces of the body provide a universal entry portal for all known and emerging infectious pathogenic microbes. Therefore, it seems that special vaccination strategies are needed for vaccines that can hinder the entry capability of pathogenic microbes through the mucosal surfaces. Lactic acid bacteria are widely used in the food industry and are presently applied as delivery vehicles in many biological investigations. Among these bacteria, Lactococcus lactis is considered as a promising candidate for mucosal live vaccines to be used as an antigen delivery vector. This is an attractive alternative and a safer vaccination strategy against the pathogens, compared to other conventional methods. In this review, we summarized the applications of $L$. lactis as a mucosal vector of vaccine delivery for heterologous expression of proteins and its applications in biotechnology.
\end{abstract}

KEYWORDS: Lactococcus lactis, Live vector, Live delivery vaccines, Mucosal vaccines.

\section{INTRODUCTION}

In 1980, Walter Schaffner demonstrated that bacteria are capable of transferring the genetic material into mammalian cells in vitro. Since then, bacteria have been suggested to be used as new transferring vectors for the plasmid vaccines [13]. Later, it was shown that Gram positive bacteria, such as Listeria monocytogenes, were also able to deliver plasmid DNA [4]. Moreover, attenuated or artificially engineered invasive bacteria have been tested as a vehicle for the transgene delivery [5].

For centuries, people had recognized that the consumption of ferm entedproducts can have a positive effect on their health. Over recent decades, these probiotics such as lactic acid bacteria (LAB) have been classified as "generally recognized as safe" (GRAS) by the United States Food and Drug Administration (USFDA) [6]. Moreover, some LAB were shown to be able to stimulate the immune system of the hosts like adjuvants because of their probiotic properties and immunomodulation capacities [7]. While both pathogenic and commensal bacteria have benefits and drawbacks as mucosal delivery vehicles, LAB are more desirable for their safety and fewer side effects [8].

Lactococcus lactis has a good record of safe usage in food fermentation industries and is able to survive the passage through the gastrointestinal tract of humans and animals [9]. Moreover, it does not invade or colonize the mucosal surfaces

*Corresponding Author: Seyed Davood Hosseini, Razi vaccine and serum Research institute, Arak Branch, Arak, Iran.

Email: hosseinida@yahoo.com

Tel/Fax: (+98) 8633544702
Of the host with a retention time of 2 to 3 days. Interestingly, $L$. lactis has no lipopolysaccharide and for this reason, it does not induce strong host immune responses [10-12]. Thanks to the genetic tools which have been developed in recent years and the availability of the nucleotide sequence of the complete genome of L. lactis, it would be easier now for researchers to manipulate the genes of interest and to produce and deliver proteins to the host mucosal surfaces, through the oral, genital or intranasal routes using L. lactis delivery systems. [13, 12, 14, 15]. Presently, a number of studies are being planned to use recombinant $L$. lactis for induction of immune responses against antigens [9].

In this review, we will focus on the potential of L. lactis as a vehicle for the delivery of oral vaccines. The first part of the review concentrates primarily with the interactions between L. lactis and the mucosal tissues of the host. In the second part, an overview regarding the new molecular biology studies for efficient expression of antigens from pathogenic organisms by L. lactis will be given. In the next parts, some early outcomes of such antigen producing bacteria as well as the available commercial expression systems and safety concerns will be summarized.

PART 1: L. lactis and interaction with the mucosal tissues of the host

Microfold (M) cells play an important role in the beginning of the mucosal immune response and perpetuity of the mucosal surface barrier. $M$ cells transport pathogens and foreign molecules from the apical lumen side to the basal side via transcytosis. M cells do not have a mucus layer on their apical 
side $[16,5]$. This character allows $M$ cells to uptake antigens efficiently from the luminal space. The basal side of $\mathrm{M}$ cells which is formed from invaginated membranes has pockets and house dendritic cells (DCs; Fig. 1). These DCs take up transported pathogens and molecules and help to manage the adaptive immune responses [17]. This close vicinity of DCs to $\mathrm{M}$ cells is especially remarkable due to the rapid process of the transcytosed antigens and the presentation of the antigenic peptides to $\mathrm{B}$ and $\mathrm{T}$ cells for induction of the immune responses. Germinal center, contains a network of follicular DCs and many B cells, including IgA-producing B cells [16]. These B cells can migrate into the intestinal lamina propria and secrete $\operatorname{IgA}(\operatorname{sg} \mathrm{A})$. The space between neighboring follicles in the Peyer's patches (PPs) is called intrafollicular region (IFR). Intrafollicular region is full of $\mathrm{T}$ cells and DCs which help to administer the adaptive immune responses in the PPs [18].
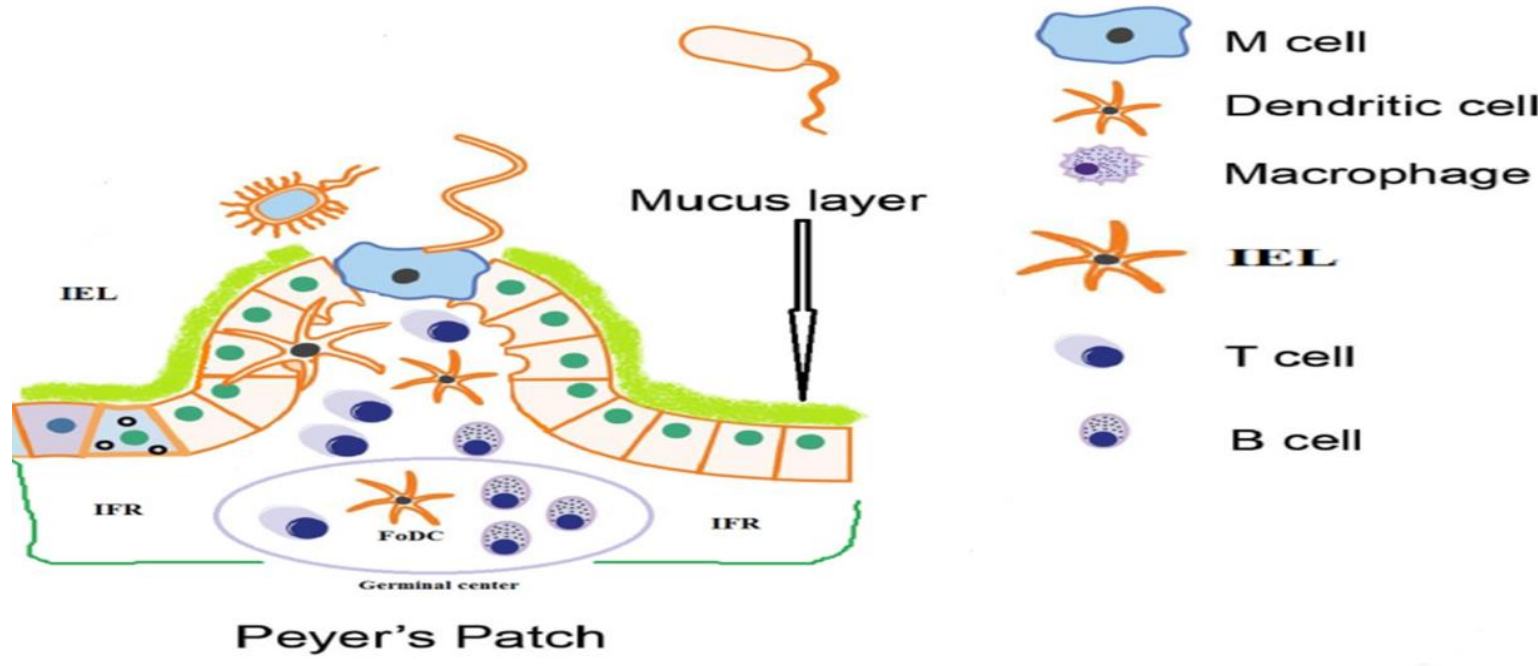

Macrophage
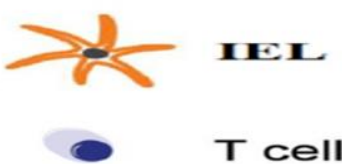

B cell

Fig. 1. Schematic representation of a Peyer's patches follicle, M cells and the different immune cell populations. M cells have no mucus. IFR: intra-follicular region, B: B cells, IEL: intraepithelial lymphocyte, T: T cells, FoDC: follicular dendritic cell, DC: dendritic cells.

L. lactis can enter through the intestinal epithelial cells (IECs) or $\mathrm{M}$ cells. Following internalization, it reproduces in the phagocytic cells, and causes cellular death mechanism to spread to deeper layers. In a usual manner, inflammatory response are induced and infiltration of polymorphonuclear cells causes the activation of inflammatory cascades and production of proinflammatory cytokines and severe tissue damages. Therefore, the microbes from the infected lesions are cleared and the production of antimicrobial neutralizing antibodies occurs. This will eventually tiger a dynamic immune response, engaging the native and acquired mucosal responses [19-21].

\section{PART 2: LAB as a live vesicle for mucosal vaccine}

\section{delivery}

The development of the molecular methods and genetic manipulation have helped to effectively produce antigens and curative molecules at different cellular localizations in LAB and to deliver DNA and protein to eukaryotic cells, making these bacteria very useful as live vaccines. A remarkable property of genetically-engineered LAB is that their mucosal administration elicits both systemic and mucosal immunity [12]. Among the LAB, L. lactis is a promising candidate for development of the future vaccines because: (i) many genetic tools have so far been developed for it, (ii) its genome is completely sequenced, (iii) its safety properties have been revealed.

Iwaki and collaborators in 1990 were one of the first researcher $\mathrm{s}$ who attempted to use $L$. lactis as live vaccines [22]. Many investigations with recombinant $L$. lactis strains were later performed and either protection or incomplete protection have been observed in this regard [23]. lately, the use of LAB LAB DNA vaccine delivery vehicles has been studied as an vaccination [24-26]. A few recent studies in which LAB have been used as a vaccine, are reviewed in the next part.

PART 3: Early outcomes of $\boldsymbol{L}$. lactis for vaccine delivery The first investigation for a L. lactis-based mucosal vaccine was against Streptococcus mutans surface protein (Pac). It has been documented that when killed recombinant L. lactis which had cytoplasmic expression of surface protein antigen (PAc) was supplied orally, $\operatorname{IgA}$ and $\operatorname{IgG}$ responses against the antigen were observed [22]. Moreover, Clostridium tetani toxin fragment $\mathrm{C}$ (TTFC - tetanus toxin fragment C), expressed by L. lactis strain has shown highly immunogenic properties. [27, 28]. Studies have revealed that the nasal route of surface displayed recombinant TTFC was preferred [29]. Moreover, the intracellularly-expressed T3SS (type III secretory system protein) vaccines against EspB which was used orally has shown no specific serum and fecal antibodies after ten days and intraperitoneal vaccination of the EspB protein in BALB/c mice has increased serum IgG and fecal IgA levels [30].

The comparative efficacy of a FaeG (fimbria adhesion)-based vaccine has been explored by oral and intramuscular administration in piglets [31]. The intramuscular inoculation with recombinant $L$. lactis expressing FaeG has shown to induce specific systemic responses. In another study, nasal inoculation with recombinant L. lactis expressing conserved stretch peptide of the avian influenza M2 antigen in birds, has resulted in increased survival times against high pathogenic avian influenza virus A subtype $\mathrm{H} 5 \mathrm{~N} 2$ [32]. In another challenge in mice, nasal and bronchoalveolar lavages (BAL) inoculated with recombinant $L$. lactis expressing Brucella abortus $\mathrm{Cu}-\mathrm{Zn}$ superoxide dismutase (SOD), has shown SODspecific IgM and SOD-specific sIgA antibodies which could 
protect the mice against virulent B. abortus strain [9]. It has been shown that orally and intranasally vaccination with L. lactis strain expressing Rhodococcus equi VapA (virulenceassociated protein A) in mice, have led to a specific mucosal immune response against $\mathrm{VapA}$ in challenge with a virulent strain of R. equi [33].

In another investigation, intragastric route vaccination with recombinant $L$. lactis producing VP7 has been shown to induce systemic IgG antibody response against rotavirus [34]. Here, when mice were orally immunized with recombinant $L$. lactis producing intracellularly rotavirus spike-protein subunit VP8, significant levels of intestinal IgA antibodies were produced while the secreted, cytoplasmic expressed protein or surface anchored-antigen induced anti-VP8 antibodies at both mucosal and systemic levels [34]. Orally administration of recombinant L. lactis producing enterotoxin B of Staphylococcus aureus in mice has been demonstrated to elicit cellular or systemic immune responses and increased survival rate in vaccinated mice against S. aureus [35]. Moreover, vaccinated animal with $L$. lactis expressing papillomavirus type16 (HPV16) E7 protein, persuasion humoral and cellular immune responses have been able to protect the animals against HPV-16 induced tumors [36].

In mice, intranasal administration of recombinant $L$. lactis strain expressing Yersinia pseudotuberculosis low-calcium response $\mathrm{V}(\mathrm{LcrV})$ antigen has been able to elicit specific systemic and mucosal antibody and cellular immune responses against Yersinia infection. LcrV is a major bacterial pathogenicity determinant that induces the production of interleukin-10 (IL-10) and takes part in the secretion and translocation of Yersinia toxin proteins into the phagocytes. This investigation has shown that the antigen and the administration route of vaccine are very important and can influence antigen-specific immune responses [37, 38]. These studies emphasize the practicality of vaccination or therapy with recombinant $L$. lactis due to their capacity for inducing mucosal and systemic immune responses [39, 40].

PART 4: $L$. lactis delivery systems:

The strains, plasmids and plasmid properties of L. lactis are summarized in Table 1. All used strains are obtained from L. lactis subspecies cremoris MG1363, a plasmid-free progeny of the dairy starter strain NCDO712.

NZ9000 is the most commonly used host strain and the standard host strain for nisin-regulated gene expression (NICE®). Moreover in this strain, nisK and nisR genes were cloned into the pepN gene of MG1363 [41]. In NZ9100 strain, nisin genes were inserted into a neutral locus. The replicon of the vectors pNZ8008, pNZ8148, pNZ8149 and pNZ8150 are the same and are resulted from the L. lactis plasmid pSH71. These Plasmids can replicate in many Gram-positive bacteria such as Streptococcus thermophilus and Lactobacillus plantarum as well as E. coli with a recA+ strain such as MC1061.

The pNZ8149 vector has the lacF gene as a food grade selection marker. For the transformation process, this vector needs a host strain with the lactose operon and without lacF gene, such as L. lactis NZ3900 [42, 43]. In pNZ9530, the replication genes have come from Enterococcus faecalis pAMß1plasmid which replicate only in Gram-positive host strains, for example L. lactis and Lactobacillus plantarum $[44,45]$.

Table 1. L. lactis strains and plasmids for expression

\begin{tabular}{|c|c|c|c|}
\hline Strains & Plasmids & Plasmids property & Reference \\
\hline L. lactis NZ9000/NZ9100 & pNZ8008 & Reference plasmid for nisin, intracellular expression & {$[41,46]$} \\
\hline L. lactis NZ9000/NZ9100 & pNZ8148 & $\mathrm{Cm}^{\mathrm{R}}$, intracellular expression & [41] \\
\hline L. lactis NZ9000/NZ9100 & pNZ8150 & $\mathrm{Cm}^{\mathrm{R}}$, intracellular expression & [41] \\
\hline L. lactis NZ9000/NZ9100 & pNZ9530 & low copy plasmid, intracellular expression & {$[41,45]$} \\
\hline L. lactis NZ3000 & pNZ8149 & lacF $^{+}$, food grade, intracellular expression & {$[43,47]$} \\
\hline L. lactis NZ3900 & pNZ8149 & lacF $^{+,}$food grade, intracellular expression & {$[43,47]$} \\
\hline L. lactis NZ3910 & pNZ8149 & lacF $^{+}$food grade, intracellular expression & {$[48,47]$} \\
\hline L. lactis NZ9000/NZ9100 & pNZ8120 & $\mathrm{Cm}^{\mathrm{R},}$ NICE Secretion vectors & [49] \\
\hline L. lactis NZ9000/NZ9100 & pNZ8121 & $\mathrm{Cm}^{\mathrm{R},}$ NICE Secretion vectors & [49], unpublished \\
\hline L. lactis NZ9000/NZ9100 & pNZ8122 & $\mathrm{Cm}^{\mathrm{R},}$ NICE Secretion vectors & [50] \\
\hline L. lactis NZ9000/NZ9100 & pNZ8123 & $\mathrm{Cm}^{\mathrm{R},}$ NICE Secretion vectors & unpublished \\
\hline L. lactis NZ9000/NZ9100 & pNZ8124 & $\mathrm{Cm}^{\mathrm{R},}$ NICE Secretion vectors & [51], unpublished \\
\hline L. lactis NZ3900/NZ3910 & pNZ8151 & lacF $^{+}$food grade, intracellular expression & [41] \\
\hline L. lactis NZ9130 & pNZ8152 & lacF $F^{+}$food grade, intracellular expression & {$[48,41]$} \\
\hline
\end{tabular}

$\mathrm{Cm}^{\mathrm{R}}$ : Chloramphenicol resistance

\section{PART 5: Safety Concerns}

A grave concern about the use of live LAB mucosal vaccines has been the risk of releasing genetically modified organisms to the environment. Such manipulated bacteria which produce antigens and antibiotic markers, may lead to horizontal transfer of the plasmid to other bacteria Therefore, the use of auxotrophic mutants can prevent the reproduction of such organisms in the environment. Furthermore, food-grade plasmids and auxotrophic strains can be used to solve the problem about horizontal transfer of plasmids which carry antibiotic resistance markers to the environmental and host's microflora.

For this reason, scientists have replaced the thyA gene (coding for thymidylate synthase) with the gene for human IL-10 in
L. lactis, thereby they have made an auxotrophic strain dependent on thymidine which cannot survive in the environment [52]. Moreover, a recombinant L. lactis has been made which contains the LLO (Listeriolysin O of Listeria monocytogenes) gene. This was considered to reduce the use of antibiotic markers and also, the probability of horizontal gene transfer to other bacteria in the natural environment was highly minimized [53].

In this paper, we reviewed some $\mathrm{LAB}$ mucosal vaccines which have shown some advantages compared to injected vaccines, which could be listed as: (a) their ability to induce the systemic and mucosal immune responses in the host, (b) their ease of manipulating, (c). their lack of requirement to be handled by expert personnel. Moreover, the safety concerns about the 
release of recombinant plasmids and chromosomally-modified bacterial strains in the environment can be controlled as we discussed in text. For these reasons, LAB are considered as suitable mucosal delivery vectors for heterologous antigens and can be used in clinical trials.

\section{CONFLICT OF INTEREST}

The authors thank Dr. Hosseini, the head of Razi vaccine and serum Research institute, Arak Branch, Dr. Jafari, Department of Microbiology, Islamic Azad University, Arak Branch, Dr. Akbary, Department of Microbiology, Islamic Azad University, Arak Branch for their constant support, guidance and inspiration.

\section{REFERENCES}

1. Grillot-Courvalin C, Goussard S, Huetz F, Ojcius DM, Courvalin P. Functional gene transfer from intracellular bacteria to mammalian cells. Nat Biotechnol. 1998;16(9):862-6. doi:10.1038/nbt0998-862.

2. Sizemore DR, Branstrom AA, Sadoff JC. Attenuated Shigella as a DNA delivery vehicle for DNA-mediated immunization. Science. 1995;270(5234):299-302.

3. Vassaux G, Nitcheu J, Jezzard S, Lemoine NR. Bacterial gene therapy strategies. J Pathol. 2006;208(2):290-8. doi:10.1002/path.1865.

4. Becker PD, Noerder M, Guzman CA. Genetic immunization: bacteria as DNA vaccine delivery vehicles. Hum Vaccin. 2008;4(3):189-202.

5. Seow Y, Wood MJ. Biological gene delivery vehicles: beyond viral vectors. Mol Ther. 2009;17(5):767-77. doi:10.1038/mt.2009.41.

6. Pellissery AJ, Nair UR. Lactic Acid Bacteria as Mucosal Delivery Vaccine. Advances in Animal and Veterinary Sciences. 2013;1(6):183 - 7

7. Seegers JF. Lactobacilli as live vaccine delivery vectors: progress and prospects. Trends Biotechnol. 2002;20(12):508-15.

8. del Rio B, Dattwyler RJ, Aroso M, Neves V, Meirelles L, Seegers JF et al. Oral immunization with recombinant lactobacillus plantarum induces a protective immune response in mice with Lyme disease. Clin Vaccine Immunol. 2008;15(9):1429-35. doi:10.1128/CVI.00169-08.

9. Saez D, Fernandez P, Rivera A, Andrews E, Onate A. Oral immunization of mice with recombinant Lactococcus lactis expressing $\mathrm{Cu}, \mathrm{Zn}$ superoxide dismutase of Brucella abortus triggers protective immunity. Vaccine. 2012;30(7):1283-90. doi:10.1016/j.vaccine.2011.12.088.

10. Siezen RJ, Kok J, Abee T, Schaafsma G. Lactic acid bacteria: genetics, metabolism and applications. Antonie Van Leeuwenhoek. 2002;82(1-4):1. 11. Gui-hua W, Xi-lin H, Li-yun Y, Jian-kuil L, Chun-hual W. Studies on Mucosal Immunity Induced by Transmissible Gastroenteritis Virus Nucleocapsid Protein Recombinant Lactobacillus casei in Mice and Sow. Agricultural Sciences in China. 2009;8(2):231-7.

12. D'Souza R, Pandeya DR, Hong S-T. Lactococcus Lactis: An efficient Gram positive cell factory for the production and secretion of recombinant protein. Biomedical Research 2012;23 (1): 1-7.

13. Wyszynska A, Kobierecka P, Bardowski J, Jagusztyn-Krynicka EK. Lactic acid bacteria--20 years exploring their potential as live vectors for mucosal vaccination. Appl Microbiol Biotechnol. 2015;99(7):2967-77. doi:10.1007/s00253-015-6498-0.

14. Asensi GF, de Sales NF, Dutra FF, Feijo DF, Bozza MT, Ulrich RG et al. Oral immunization with Lactococcus lactis secreting attenuated recombinant staphylococcal enterotoxin $\mathrm{B}$ induces a protective immune response in a murine model. Microb Cell Fact. 2013;12:32. doi: $10.1186 / 1475-2859-12-32$.

15. Bermudez-Humaran LG, Kharrat P, Chatel JM, Langella P. Lactococci and lactobacilli as mucosal delivery vectors for therapeutic proteins and DNA vaccines. Microb Cell Fact. 2011;10 Suppl 1:S4. doi:10.1186/14752859-10-S1-S4.

16. Mestecky J, Strober W, Russell MW, Cheroutre H, Lambrecht BN, Kelsall BL. Mucosal Immunology. Academic Press is an imprint of Elsevier. 2015;2:31-42.

17. Yamamoto M, Pascual DW, Kiyono H. M cell-targeted mucosal vaccine strategies. Curr Top Microbiol Immunol. 2012;354:39-52. doi:10.1007/82_2011_134.

18. Shakya $\overline{A K}$, Chowdhury MY, Tao W, Gill HS. Mucosal vaccine delivery: Current state and a pediatric perspective. J Control Release. 2016;240:394-413. doi:10.1016/j.jconrel.2016.02.014.

19. Adachi K, Kawana K, Yokoyama T, Fujii T, Tomio A, Miura S et al.
Oral immunization with a Lactobacillus casei vaccine expressing human papillomavirus (HPV) type $16 \mathrm{E} 7$ is an effective strategy to induce mucosal cytotoxic lymphocytes against HPV16 E7. Vaccine. 2010;28(16):2810-7. doi:10.1016/j.vaccine.2010.02.005.

20. Bermudez-Humaran LG. Lactococcus lactis as a live vector for mucosal delivery of therapeutic proteins. Hum Vaccin. 2009;5(4):264-7.

21. Lebeer S, Vanderleyden J, De Keersmaecker SC. Host interactions of probiotic bacterial surface molecules: comparison with commensals and pathogens. Nat Rev Microbiol. 2010;8(3):171-84. doi:10.1038/nrmicro2297.

22. Iwaki M, Okahashi N, Takahashi I, Kanamoto T, Sugita-Konishi Y, Aibara K et al. Oral immunization with recombinant Streptococcus lactis carrying the Streptococcus mutans surface protein antigen gene. Infect Immun. 1990;58(9):2929-34

23. Pontes DS, de Azevedo MS, Chatel JM, Langella P, Azevedo V, Miyoshi A. Lactococcus lactis as a live vector: heterologous protein production and DNA delivery systems. Protein Expr Purif. 2011;79(2):16575. doi:10.1016/j.pep.2011.06.005.

24. Guimaraes VD, Innocentin S, Lefevre F, Azevedo V, Wal JM, Langella $\mathrm{P}$ et al. Use of native lactococci as vehicles for delivery of DNA into mammalian epithelial cells. Appl Environ Microbiol. 2006;72(11):7091-7. doi:10.1128/AEM.01325-06.

25. Chatel JM, Pothelune L, Ah-Leung S, Corthier G, Wal JM, Langella P. In vivo transfer of plasmid from food-grade transiting lactococci to murine epithelial cells. Gene Ther. 2008;15(16):1184-90. doi:10.1038/gt.2008.59.

26. Tao L, Pavlova SI, Ji X, Jin L, Spear G. A novel plasmid for delivering genes into mammalian cells with noninvasive food and commensal lactic $\begin{array}{lll}\text { acid bacteria. } & \text { Plasmid. }\end{array}$ doi:10.1016/j.plasmid.2010.09.001.

27. Wells JM, Wilson PW, Norton PM, Gasson MJ, Le Page RW. Lactococcus lactis: high-level expression of tetanus toxin fragment $\mathrm{C}$ and protection against lethal challenge. Mol Microbiol. 1993;8(6):1155-62.

28. Pellissery AJ, Nair UR. Lactic Acid Bacteria as Mucosal Delivery Vaccine. Advances in Animal and Veterinary Sciences. 2013;1(6):183 - 7. 29. Nouaille S, Ribeiro LA, Miyoshi A, Pontes D, Le Loir Y, Oliveira SC et al. Heterologous protein production and delivery systems for Lactococcus lactis. Genet Mol Res. 2003;2(1):102-11.

30. Ahmed B, Loos M, Vanrompay D, Cox E. Mucosal priming of the murine immune system against enterohemorrhagic Escherichia coli O157:H7 using Lactococcus lactis expressing the type III secretion system protein EspB. Vet Immunol Immunopathol. 2013;152(1-2):141-5. doi:10.1016/j.vetimm.2012.09.019.

31. Liu S, Li Y, Xu Z, Wang Y. Subcutaneous or oral immunization of mice with Lactococcus lactis expressing F4 fimbrial adhesin FaeG. J Vet Med Sci. 2013;75(6):779-84.

32. Ferbas J, Belouski SS, Horner M, Kaliyaperumal A, Chen L, Boyce M et al. A novel assay to measure B cell responses to keyhole limpet haemocyanin vaccination in healthy volunteers and subjects with systemic lupus erythematosus. Br J Clin Pharmacol. 2013;76(2):188-202. doi: $10.1111 /$ bcp. 12172 .

33. Cauchard S, Bermudez-Humaran LG, Blugeon S, Laugier C, Langella $\mathrm{P}$, Cauchard J. Mucosal co-immunization of mice with recombinant lactococci secreting VapA antigen and leptin elicits a protective immune response against Rhodococcus equi infection. Vaccine. 2011;30(1):95-102. doi:10.1016/j.vaccine.2011.10.026.

34. Marelli B, Perez AR, Banchio C, de Mendoza D, Magni C. Oral immunization with live Lactococcus lactis expressing rotavirus VP8 subunit induces specific immune response in mice. J Virol Methods. 2011;175(1):28-37. doi:10.1016/j.jviromet.2011.04.011.

35. Asensi GF, de Sales NF, Dutra FF, Feijo DF, Bozza MT, Ulrich RG et al. Oral immunization with Lactococcus lactis secreting attenuated recombinant staphylococcal enterotoxin B induces a protective immune response in a murine model. Microb Cell Fact. 2013;12:32. doi:10.1186/1475-2859-12-32.

36. Bermudez-Humaran LG, Cortes-Perez NG, Lefevre F, Guimaraes V, Rabot S, Alcocer-Gonzalez JM et al. A novel mucosal vaccine based on live Lactococci expressing E7 antigen and IL-12 induces systemic and mucosal immune responses and protects mice against human papillomavirus type 16-induced tumors. J Immunol. 2005;175(11):7297-302.

37. Cortes-Perez NG, Lefevre F, Corthier G, Adel-Patient K, Langella P, Bermudez-Humaran LG. Influence of the route of immunization and the nature of the bacterial vector on immunogenicity of mucosal vaccines based on lactic acid bacteria. Vaccine. 2007;25(36):6581-8. doi:10.1016/j.vaccine.2007.06.062.

38. Daniel C, Sebbane F, Poiret S, Goudercourt D, Dewulf J, Mullet C et al. 
Protection against Yersinia pseudotuberculosis infection conferred by a Lactococcus lactis mucosal delivery vector secreting LcrV. Vaccine. 2009;27(8):1141-4. doi:10.1016/j.vaccine.2008.12.022.

39. Xin KQ, Hoshino Y, Toda Y, Igimi S, Kojima Y, Jounai $\mathrm{N}$ et al. Immunogenicity and protective efficacy of orally administered recombinant Lactococcus lactis expressing surface-bound HIV Env. Blood. 2003;102(1):223-8. doi:10.1182/blood-2003-01-0110.

40. Robinson K, Chamberlain LM, Lopez MC, Rush CM, Marcotte H, Le Page RW et al. Mucosal and cellular immune responses elicited by recombinant Lactococcus lactis strains expressing tetanus toxin fragment $\mathrm{C}$. Infect Immun. 2004;72(5):2753-61.

41. Mierau I, Kleerebezem M. 10 years of the nisin-controlled gene expression system (NICE) in Lactococcus lactis. Appl Microbiol Biotechnol. 2005;68(6):705-17. doi:10.1007/s00253-005-0107-6

42. Vos WMD. Gene cloning and expression in lactic streptococci. FEMS Microbiology Letters 1987;46(3):281 -95.

43. de Ruyter PG, Kuipers OP, de Vos WM. Controlled gene expression systems for Lactococcus lactis with the food-grade inducer nisin. Appl Environ Microbiol. 1996;62(10):3662-7.

44. Simon D, Chopin A. Construction of a vector plasmid family and its use for molecular cloning in Streptococcus lactis. Biochimie. 1988;70(4):55966.

45. Kleerebezem M, Beerthuyzen MM, Vaughan EE, de Vos WM, Kuipers OP. Controlled gene expression systems for lactic acid bacteria: transferable nisin-inducible expression cassettes for Lactococcus, Leuconostoc, and Lactobacillus spp. Appl Environ Microbiol. 1997;63(11):4581-4.

46. de Ruyter PG, Kuipers OP, Beerthuyzen MM, van Alen-Boerrigter I, de Vos WM. Functional analysis of promoters in the nisin gene cluster of Lactococcus lactis. J Bacteriol. 1996;178(12):3434-9.
47. Mierau I, Leij P, van Swam I, Blommestein B, Floris E, Mond J et al. Industrial-scale production and purification of a heterologous protein in Lactococcus lactis using the nisin-controlled gene expression system NICE: the case of lysostaphin. Microb Cell Fact. 2005;4:15. doi:10.1186/14752859-4-15.

48. Bron PA, Benchimol MG, Lambert J, Palumbo E, Deghorain M, Delcour $J$ et al. Use of the alr gene as a food-grade selection marker in lactic acid bacteria. Appl Environ Microbiol. 2002;68(11):5663-70.

49. Vos P, Simons G, Siezen RJ, de Vos WM. Primary structure and organization of the gene for a procaryotic, cell envelope-located serine proteinase. J Biol Chem. 1989;264(23):13579-85.

50. Novotny R, Scheberl A, Giry-Laterriere M, Messner P, Schaffer C. Gene cloning, functional expression and secretion of the S-layer protein SgsE from Geobacillus stearothermophilus NRS 2004/3a in Lactococcus lactis. FEMS Microbiol Lett. 2005;242(1):27-35.

51. van Asseldonk M, Rutten G, Oteman M, Siezen RJ, de Vos WM, Simons G. Cloning of usp45, a gene encoding a secreted protein from Lactococcus lactis subsp. lactis MG1363. Gene. 1990;95(1):155-60

52. Steidler L, Neirynck S, Huyghebaert N, Snoeck V, Vermeire A, Goddeeris B et al. Biological containment of genetically modified Lactococcus lactis for intestinal delivery of human interleukin 10. Nat Biotechnol. 2003;21(7):785-9. doi:10.1038/nbt840.

53. Bahey-El-Din M, Casey PG, Griffin BT, Gahan CG. Efficacy of a Lactococcus lactis DeltapyrG vaccine delivery platform expressing chromosomally integrated hly from Listeria monocytogenes. Bioeng Bugs. 2010;1(1):66-74. doi:10.4161/bbug.1.1.10284. 